\title{
Local RNA Translation at the Synapse and in Disease
}

\author{
Liqun Liu-Yesucevitz, ${ }^{1}$ Gary J. Bassell,,${ }^{3,4}$ Aaron D. Gitler, ${ }^{8}$ Anne C. Hart, ${ }^{9}$ Eric Klann, ${ }^{10}$ Joel D. Richter, ${ }^{11}$ \\ Stephen T. Warren, ${ }^{5,6,7}$ and Benjamin Wolozin ${ }^{1,2}$ \\ Departments of ${ }^{1}$ Pharmacology and ${ }^{2}$ Neurology, Boston University School of Medicine, Boston, Massachusetts 02118, Departments of ${ }^{3}$ Cell Biology, \\ ${ }^{4}$ Neurology, ${ }^{5}$ Human Genetics, ${ }^{6}$ Biochemistry, and ${ }^{7}$ Pediatrics, Emory University School of Medicine, Atlanta, Georgia 30322, ${ }^{8}$ Department of Cell and \\ Developmental Biology, Perelman School of Medicine, University of Pennsylvania, Philadelphia, Pennsylvania 19104, ${ }^{9}$ Department of Neuroscience, Brown \\ University, Providence, Rhode Island 02912, ${ }^{10}$ Center for Neural Science, New York University, New York, New York 10003, and ${ }^{11}$ Program in Molecular \\ Medicine, University of Massachusetts Medical School, Worcester, Massachusetts 01605
}

Local regulation of protein synthesis in neurons has emerged as a leading research focus because of its importance in synaptic plasticity and neurological diseases. The complexity of neuronal subcellular domains and their distance from the soma demand local spatial and temporal control of protein synthesis. Synthesis of many synaptic proteins, such as GluR and PSD-95, is under local control. mRNA binding proteins (RBPs), such as FMRP, function as key regulators of local RNA translation, and the mTORC1 pathway acts as a primary signaling cascade for regulation of these proteins. Much of the regulation occurs through structures termed RNA granules, which are based on reversible aggregation of the RBPs, some of which have aggregation prone domains with sequence features similar to yeast prion proteins. Mutations in many of these RBPs are associated with neurological diseases, including FMRP in fragile X syndrome; TDP-43, FUS (fused in sarcoma), angiogenin, and ataxin-2 in amyotrophic lateral sclerosis; ataxin-2 in spinocerebellar ataxia; and SMN (survival of motor neuron protein) in spinal muscular atrophy.

\section{Introduction}

Neurons are cells with complex, polarized, highly elaborated processes that extend great distances. The large distance of synapses from the soma creates a fundamental challenge for the neuron: neurons must prevent synthesis of synaptic proteins during mRNA transport, yet quickly allow synthesis upon demand in response to synaptic activity. The solution to the geometry of neurons demands local mechanisms for control of RNA translation to allow synthesis of new proteins in a manner that is spatially and temporally restricted.

mRNA binding proteins (RBPs) have emerged as one of the major mechanisms for local regulation of RNA translation/protein synthesis. Regulation of the localization, stability, and translation of mRNAs is mediated in part by RBPs that bind to mRNAs in untranslated regions ( $3^{\prime}$-UTR and/or 5'-UTR) or coding regions of mRNA (Martin and Ephrussi, 2009; Richter and Klann, 2009). RBPs regulate mRNA distribution and metabolism by consolidating RNA-protein complexes to form RNA granules in which translation is repressed (Kiebler and Bassell, 2006; Thomas et al., 2011). Upon synaptic demand, mRNA is shuttled from storage granules to the synapse where RNA translation is rapidly initiated. The consolidation to form RNA granules occurs through a mechanism of reversible protein aggregation of RBPs

Received Aug. 9, 2011; revised Aug. 16, 2011; accepted Aug. 17, 2011.

This work was supported by National Institutes of Health Grant NS066108, National Institute of Environmental Health Sciences Grant ES15567, and National Institute of Neurological Disorders and Stroke Grant NS060872 (B.W.).

Correspondence should be addressed to Dr. Benjamin Wolozin, Departments of Pharmacology and Neurology,

Boston University School of Medicine, 72 East Concord Street, R614, Boston, MA 02118-2526. E-mail: bwolozin@bu.edu.

DOI:10.1523/JNEUROSCI.4105-11.2011

Copyright $\odot 2011$ the authors $\quad 0270-6474 / 11 / 3116086-08 \$ 15.00 / 0$ such as TIA-1, TIAR, and G3BP, which contain polyglutamineand asparagine-rich domains that aggregate readily and share homology (physical and functional) with the yeast prion protein Sup35 (Anderson and Kedersha, 2008). Dendrites contain at least three different types of RNA granules. Ribonucleoprotein particles (RNPs) appear to function in transport and storage of mRNA transcripts. Stress granules (SGs) sequester nonessential capped mRNAs in response to stress, which promotes translation of essential stress response proteins, such as HSP70. Processing bodies (P-bodies) regulate degradation of mRNA (Kiebler and Bassell, 2006; Wang et al., 2010). Working in concert with microRNA (miRNA) and microtubules, these RNA granules regulate the distribution, translation, and degradation of mRNA transcripts throughout the neuron.

Although RNA granules share common protein components, each kind of RNA granule contains a distinct population of proteins and performs separate functions (Fig. 1): (1) RNA transport granules deliver transcripts to dendrites while inhibiting RNA translational activity. RBPs such as FMRP and Pumilio participate in dendritic transcript transport and function as translational repressors (Knowles et al., 1996). (2) Stress granules form transiently to reprogram RNA translation under stressful conditions. The primary consolidation-initiating SG proteins include TIA-1, TIAR, G3BP, and survival of motor neuron protein $(\mathrm{SMN})$, but a number of disease-linked proteins also associate with SGs as they expand; these proteins include FMRP, fused in sarcoma (FUS), TAR DNA binding protein-43 (TDP-43), ataxin-2 (Anderson and Kedersha, 2008). (3) P-bodies are the sites for mRNA degradation, often integrating with miRNA machinery. Dcpla (decapping enzyme 1a) is a RBP that is classically used to identify P-bodies (Parker and Sheth, 2007). Dendritic 


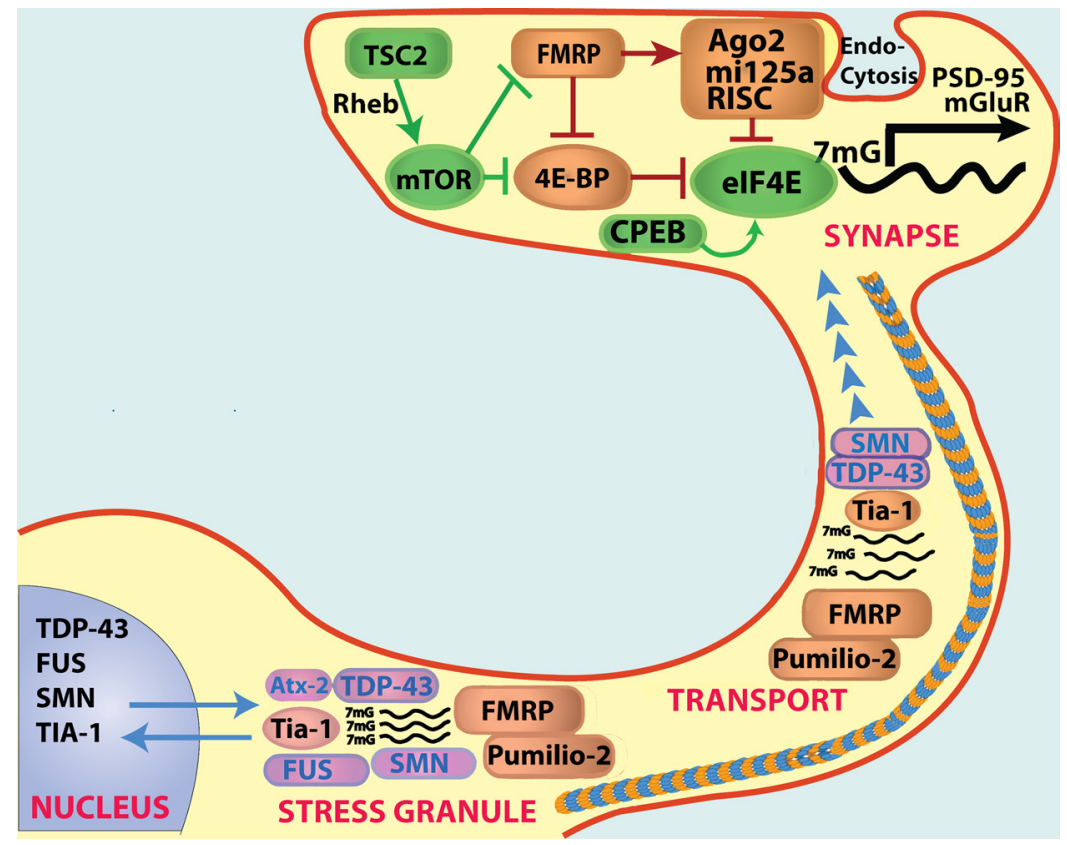

Figure 1. Translational control by RBPs. RBPs act in the nucleus, where they have been implicated in splicing and transcription. The same RBPs also exhibit important roles outside the nucleus. RBPs function to transport mRNAs to the synapse, during which they silence translation. At the synapse, RBPs function in a complex network regulating local translation. Finally, in response to stress, RBPs sequester $7 \mathrm{mG}$ capped mRNA in large aggregates, which allows synthesis of protective uncapped mRNA, such as heat shock proteins. Orange, RBPs that function silence translation. Magenta, RBPs that function in splicing and transport. Green, RBPs that activate RNA translation. Blue/orange striped line, Microtubules.

RNA granules do not function as isolated particles, but instead constantly interact with each other exchanging transcripts and proteins. The dynamics of RNA granules control all stages of mRNA processing including biogenesis, translation, and degradation.

The RBPs that make up RNA granules are emerging as major sources of mutations linked to neurological diseases. For instance, impaired expression of FMRP, due to trinucleotide repeat expansions, is the cause of fragile $\mathrm{X}$ mental retardation syndrome, which is the most common cause of inherited mental retardation (Kelleher and Bear, 2008; Darnell et al., 2011). Expanded trinucleotide repeats in several different ataxin genes are the cause of spinocerebellar ataxia (Orr and Zoghbi, 2007). Mutations in SMN are linked to spinal muscular atrophy (SMA), and mutations in TDP-43 and FUS are both causes of amyotrophic lateral sclerosis (ALS) (Lefebvre et al., 1995; Lagier-Tourenne et al., 2010). Each of these proteins falls into the class of RBPs and functions in RNA granule biology. Many RBPs also exert important roles in the nucleus. For instance, TDP-43 and SMN regulate splicing of mRNA transcripts in the nucleus, and perhaps also the soma (Pellizzoni et al., 1998; Polymenidou et al., 2011). Understanding the mechanisms by which these RBPs contribute to disease represents a critical need in disease research. This minireview highlights recent advances examining the roles of RBPs in regulating dendritic local mRNA translation and discusses how dysfunction of RBPs might contribute to neurological disease. The major concepts presented below are summarized in Figure 1.

\section{Translational control at the synapse}

The observation that neuronal dendrites and dendritic spines contain mRNA and polyribosomes suggested the hypothesis that synaptic efficacy might depend, in part, on local (synaptodendritic) protein synthesis (Steward and Levy, 1982; Tiedge and
Brosius, 1996; Steward and Schuman, 2001). In situ hybridization further supports the concept of local translation by demonstrating that some mRNA transcripts are selectively localized to dendrites, which emphasizes the need for a mechanism to bind mRNAs and control their distribution (Wang et al., 2010). These and other data suggest that certain mRNAs are packaged into discrete RNPs that are transported to dendrites, presumably translationally silent until delivered to the site of action (Martin and Ephrussi, 2009). Control of "local" mRNA translation in dendrites can be divided into three main categories, although many RBPs exert functions across more than one category: specific mRNA transport to dendrites, mechanisms of translational control in dendrites (in response to synaptic stimulation), and the function of the newly synthesized proteins in synaptic efficacy.

Local translational control impacts at the level of individual synapses and synaptic networks. Synapse-stimulating agents elicit protein synthesis (Jiang and Schuman, 2002); conversely, protein synthesis inhibitors disrupt some forms of synaptic plasticity including long-term facilitation, long-term potentiation (LTP), and long-term depression (LTD) (Kang and Schuman, 1996; Martin et al., 1997; Huber et al., 2000). One form of LTP, long-lasting late-phase LTP (L-LTP), requires both gene transcription and RNA translation (Klann and Dever, 2004). Hippocampal LTD mediated by metabotropic glutamate receptors requires rapid translation of preexisting mRNA (Huber et al., 2000).

Three factors that control translation in neurons have received considerable attention: miRNAs, FMRP, and cytoplasmic polyadenylation element-binding protein (CPEB). miRNAs represent a major field of study unto themselves and have been reviewed previously (Schratt, 2009). FMRP is discussed immediately below. CPEB is a sequence-specific RBP that represses translation until stimulated, then responds to signaling events by elongating poly(A) tails of mRNA, which leads to translational activation (Richter and Klann, 2009). To accomplish these tasks, CPEB associates with a number of factors that constitute the cytoplasmic polyadenylation complex; this complex effects polyadenylation-induced translation of specific mRNAs in dendrites in response to synaptic stimulation (Wu et al., 1998). The importance of the cytoplasmic polyadenylation complex in synaptic function is highlighted by the changes in synaptic plasticity that occur in response to depletion of polyadenylation complex factors (Richter and Klann, 2009). The physical biology of CPEB highlights structural behavior potentially similar to other disease-linked RBPs. CPEB exhibits prion-like properties in yeast, and in Aplysia neurons aggregates to form amyloid-like multimers that appear to potentiate synaptic efficacy ( $\mathrm{Si}$ et al., 2010). Thus, the CPEBcontaining cytoplasmic polyadenylation complex is a coherent posttranscriptional molecular mechanism that underlies essential brain function. 


\section{FMRP and fragile $\mathrm{X}$ syndrome}

FMRP is a translational repressor that is essential for proper synaptic function. Mutations within the X-linked FMR1 gene, coding for FMRP, cause fragile X syndrome (FXS), which is the most prevalent genetic cause of intellectual disability and autism in humans (Garber et al., 2008). The most frequent mutation is an expansion within a CGG repeat located in the $5^{\prime}$-untranslated region of the first exon, where the normal repeat length of 30 increases dramatically. Subjects with repeat expansions of 55-200 are considered to have a premutation, while repeat expansions exceeding 200 cause disease and are classified as full mutations (Penagarikano et al., 2007; Garber et al., 2008). The premutation alleles are unstable and can expand upon meiotic transmission to create a full mutation. Repeat lengths exceeding 200 triplets silence transcription of the FMR1 gene causing FXS (Penagarikano et al., 2007).

FMRP is a selective RBP that is highly expressed in the brain, including in dendritic spines (Ashley et al., 1993). FMRP is found associated with ribosomes or in large RNPs in the cytoplasm or dendritic fields where it is thought to regulate local RNA translation; however, small amounts of FMRP are also present in the nucleus (Ashley et al., 1993). The RGG-box domain of FMRP mediates binding to mRNA through RNA secondary structures, such as the G-quadruplex (Melko and Bardoni, 2010). Phosphorylation of serine 500 (499 in the mouse) regulates the action of FMRP (Ceman et al., 2003). Phosphorylated FMRP suppresses translation, but dephosphorylation by protein phosphatase-2A occurs in an activity-dependent manner to enable immediate translation of bound mRNAs (Narayanan et al., 2008). In the absence of FMRP, target mRNAs normally bound to FMRP are over-translated in the dendritic spine, which leads to excess internalization of the AMPA receptor and enhanced LTD following activation of group 1 metabotropic glutamate receptors (Bassell and Warren, 2008). Conversely, mGluR5 antagonists appear to correct fragile $\mathrm{X}$ phenotypes in animal models, providing the basis for clinical trials in patients.

Recent studies indicate how FMRP selectively and reversibly represses translation of its target mRNAs at synapses. FMRP associates with the RNA-induced silencing complex (RISC) and microRNAs (Jin et al., 2004). FMRP appears to regulate translation by acting on the mi-RISC complex containing miR-125a to modulate translation of postsynaptic density protein 95 (PSD95) (Muddashetty et al., 2011). When FMRP is phosphorylated, FMRP recruits argonaute 2 (Ago2) complexes containing miR$125 \mathrm{a}$ and represses synthesis of proteins, such as PSD-95. In response to mGluR signaling, FMRP dephosphorylation leads to the release of RISC from PSD-95 mRNA, which stimulates translation (Muddashetty et al., 2011). miR-125a levels and its association with RISC is reduced at synapses of Fmrl KO mice, leading to excess translation of PSD-95 mRNA and impaired spine morphology (Muddashetty et al., 2011). Dysregulation of microRNAs may thus be a defining molecular signature of synaptic dysfunction in fragile X syndrome and other neuropsychiatric disorders.

\section{Mammalian target of rapamycin complex 1 signaling: synaptic plasticity, memory, and developmental disorders}

The mammalian target of rapamycin complex 1 (mTORC1) provides a potentially important mechanism for reversing the synaptic dysfunction associated with loss of FMRP action. A mouse model of FXS exhibits increased mTORC1 signaling (Ehninger et al., 2008; Kelleher and Bear, 2008; Hoeffer and Klann, 2010; Sharma et al., 2010). Mouse models of tuberous sclerosis com- plex (TSC) and knock-out of phosphatase and tensin homolog (PTEN) also exhibit behavior consistent with autism spectrum disorders (ASDs). Both PTEN and TSC1/2 are upstream negative regulators of mTORC1, and multiple phenotypes in PTEN and TSC mutant mice are ameliorated by rapamycin (Butler et al., 2005; Kwon et al., 2006; Ehninger et al., 2008; Zhou et al., 2009). Finally, mice with a deletion for FKBP12, the intracellular receptor of rapamycin, display perseverative and repetitive behaviors that are also tightly correlated with excessive mTORC1 signaling (Hoeffer et al., 2008). Thus, upregulation of mTORC1 signaling and cap-dependent translation may be a common molecular anomaly that contributes to aberrant behaviors in mouse models of ASD. mTORC1 and its downstream effectors represent potential therapeutic targets for the treatment of these developmental disorders.

The mechanisms by which mTORC1 regulates synaptic and cognitive function is an area of avid investigation. mTORC1 regulates cap-dependent translation initiation during both mGluRLTD, L-LTP, and memory consolidation (Tang et al., 2002; Cammalleri et al., 2003; Hou and Klann, 2004; Banko et al., 2005, 2006, 2007; Gelinas et al., 2007; Tsokas et al., 2007; Hoeffer et al., 2008, 2011). However, the mechanisms of translation control downstream of mTORC1 mediating synaptic plasticity and memory are incompletely understood. The development of novel tools such as small molecule inhibitors of eIF4E-eIF4G interactions, eIF4A, and p70 S6 kinase 1, and mice with inducible deletions of mTORC1 effector molecules hold great promise for elucidating the mechanisms underlying signaling in synaptic plasticity and memory by mTORC1 (Ran et al., 2009; Pearce et al., 2010; Hoeffer et al., 2011).

\section{RNA binding proteins and motorneuron disease}

Motorneuron diseases are frequent phenotypes associated with mutations in RBPs. Examples include mutations in SMN causing SMA (Lefebvre et al., 1995), TDP43, FUS, and angiogenin defects in ALS (Greenway et al., 2006; Lagier-Tourenne et al., 2010), mutations in SETX for ALS4 (Chen et al., 2004), long expanded polyglutamine repeat domains in ataxin-2 causing spinocerebellar ataxia-2 (Imbert et al., 1996; Elden et al., 2010; Corrado et al., 2011; Lee et al., 2011; Van Damme et al., 2011), and mutations in IGHMBP2 causing infantile spinal muscular atrophy with respiratory distress Type I (Grohmann et al., 2001). Many of the RBPs exhibit dual roles that include nuclear functions, such as splicing, and cytoplasmic functions, such as mRNA transport and silencing. Dysregulation of axonal or dendritic transport is a common phenotype associated with mutations in genes causing motorneuron disorders (Sau et al., 2011).

SMA provides an excellent vantage point for reviewing potential mechanisms by which mutations in RBPs can cause disease. Motorneurons appear to be particularly sensitive to diminished SMN function because they exhibit selective degeneration upon mutation of SMA despite its ubiquitous expression (Lefebvre et al., 1995). SMA is usually caused by decreases in protein levels of $\mathrm{SMN}$, and SMN protein levels correlate directly with the disease severity in most cases (Gennarelli et al., 1995; Lefebvre et al., 1997; Grohmann et al., 2001). Decreases in SMN function were originally considered to primarily cause splicing defects, but increased knowledge highlights other potential targets of SMN action. SMN plays an essential role in assembly of the Gemin complex, which is required for spliceosome assembly and SMN is also required in the formation of stress granules (Liu et al., 1997; Pellizzoni et al., 1998; Hua and Zhou, 2004). SMN is also found in neuronal processes within RNP complexes that include $\beta$-actin 
mRNA, which is locally translated during growth cone guidance (Sharma et al., 2005; Leung et al., 2006; Al-Ramahi et al., 2007). SMN is also part of a RNP complex with FMRP, highlighting a putative role in local translational regulation (Piazzon et al., 2008). The hypothesis that SMA defects arise solely because of splicing defects seems too simple in view of the diverse RNP granules that contain/require SMN function.

Studies identifying genetic modifiers of SMA point to potentially important connections between translational control and endocytosis. Plastin3 (PLS3) presents as a modifier of SMA in genetic screens and asymptomatic carriers of SMA mutations exhibit increased levels of PLS3 protein (Oprea et al., 2008). Increasing PLS3 levels in embryonic zebrafish greatly enhances motorneuron outgrowth following knockdown of SMN (Oprea et al., 2008). PLS3 also rescues SMN loss-of-function neuromuscular defects in Drosophila and Caenorhabditis elegans (Dimitriadi et al., 2010). PLS3 encodes a conserved and broadly expressed calcium-binding, actin-bundling protein that binds SMN (Satterfield et al., 2002). PLS3 exhibits functional connections with proteins regulating synaptic vesicle endocytosis and translational control, including Endophilin A (EndoA) and Ataxin-2 (Atx2) (Harris et al., 2000; Schuske et al., 2003). Atx2 also interacts with EndoA and TDP-43 (Nonis et al., 2008; Elden et al., 2010). Overexpressing EndoA or Ataxin-2 is toxic in yeast in the absence of Sac6p, the yeast PLS3 ortholog (Ralser et al., 2005). These data suggest that PLS3, EndoA, and Atx2 proteins interact to regulate endocytosis and mRNA translation.

Investigations of the localization of protein/miRNA complexes provide additional evidence linking translational control with endocytosis. miRNA silencing of mRNA translation requires association with the GW182 and Argonaute (Ago) protein family in the RISC complex (miRNA-induced silencing complex) (Eulalio et al., 2009b). Perturbation of Dicer function in the RISC complex causes motorneuron disease in mice and prevents translational repression by miRNA (Haramati et al., 2010). GW182 binds directly to Ago proteins and loss of GW182 prevents miRNA-mediated gene silencing across species without impacting Ago or miRNA levels (Eulalio et al., 2009a). This process links to endocytosis because Ago 2 and GW182 colocalize on the surface of endosomes, which then fuse with multivesicular bodies, for trafficking to lysosomes or recycling to the cell surface (Gibbings et al., 2009; Lee et al., 2009). Endosomal vesicles contain ligand/growth factor receptor complexes whose signaling output continues during trafficking to the multivesicular bodies. The juxtaposition of signaling receptors and GW182/Ago2 RISC complexes in endosomes, combined with the presence of complexes containing PLS3, EndoA, and Atx2, raises the possibility that receptors might regulate $\mathrm{mRNA}$ translation in endosomes and multivesicular bodies.

\section{RNA binding proteins and ALS}

ALS is a rapidly progressing neurodegenerative disease primarily affecting motorneurons (Cleveland and Rothstein, 2001). ALS occurs with an incidence of $\sim 1$ in 10,000, appears in midlife, and exhibits an average life expectancy of $\sim 3$ years after onset. Two related RBPs, TDP-43 and FUS/TLS, play key roles in the disease (Chen-Plotkin et al., 2010). In addition, mutations in the RNase/ RBP, angiogenin, cause ALS (Greenway et al., 2006). More than 40 mutations in TDP-43 have been identified in patients with familial or sporadic ALS, and nearly all mutations cluster in the C-terminal glycine-rich region (Kabashi et al., 2008; Sreedharan et al., 2008; Pesiridis et al., 2009). Almost all patients with sporadic ALS, as well as patients with familial ALS due to TDP-43 mutations, show abnormal accumulations of TDP-43 in the cytoplasm of spinal cord motorneurons (Neumann et al., 2006; Mackenzie et al., 2007). TDP-43 also accumulates in neurons in cases of frontotemporal lobar degeneration with ubiquitinpositive inclusions (FTLD-U), but in these cases TDP-43 inclusions can be cytoplasmic or nuclear. Patients with ALS caused by FUS mutations show cytoplasmic accumulation of FUS in spinal cord motorneurons. Patients with familial ALS caused develop cytoplasmic inclusions containing FUS or TDP-43, but not both (Kwiatkowski et al., 2009; Vance et al., 2009). FUS and TDP-43 both exhibit a correlation between the tendency to accrue cytoplasmic aggregates in cell models and the clinical disease severity (Dormann et al., 2010). The presence of TDP-43 pathology in ALS and FTLD-U provides a molecular link between the two diseases (Neumann et al., 2006).

Accruing evidence points to a central role for altered RNAprocessing pathways in the pathogenesis of ALS (LagierTourenne et al., 2010). TDP-43 and FUS are predominantly nuclear in dividing cells and associate with SGs during stress. Angiogenin can be nuclear or cytoplasmic, and is also secreted (Greenway et al., 2006; Emara et al., 2010). Mutations in FUS largely interfere with a noncanonical nuclear localization signal, leading to abnormal cytoplasmic localization. In neurons, TDP-43 is also present in RNA granules in dendrites and functions as synaptic activity-responsive factor; localization of TDP-43 at dendritic spine is highly regulated by neuronal activity (Wang et al., 2008). Synaptic stimulation by addition of $\mathrm{KCl}$ increases the size and numbers of mRNPs containing TDP-43 in dendrites (Wang et al., 2008). TDP-43 and FUS readily form stress granules that are largely cytoplasmic, but can be nuclear depending on the conditions. Angiogenin cleaves tRNA to promote SG formation (Emara et al., 2010). Disease-linked mutations in TDP-43 and FUS increase the tendency of TDP-43 to form SGs in response to stress (Colombrita et al., 2009; Bosco et al., 2010; Dormann et al., 2010; Liu-Yesucevitz et al., 2010; Dewey et al., 2011; McDonald et al., 2011; Sun et al., 2011). Mutations in TDP-43 also increase the tendency of TDP-43 to bind other proteins associated with SGs, such as TIA-1 or FUS (Ling et al., 2010; Liu-Yesucevitz et al., 2010). SG formation appears to be directly linked with the pathology of the disease because in cases of ALS and FTLD-U TDP-43 inclusions colocalize with SGs in human brain (Liu-Yesucevitz et al., 2010). Protein aggregation is thought to play a central role in the pathophysiology of many degenerative diseases, and the role of protein aggregation in SG formation raises the possibility that SG biology contributes to other neurodegenerative diseases. For instance, aggregates of huntingtin protein and prion protein both colocalize with SG proteins (Waelter et al., 2001; Goggin et al., 2008).

Whether the pathological process of RBP aggregation also contributes to neurodegeneration remains to be determined. Cytoplasmic sequestration reduces levels of nuclear FUS and TDP43. Neurodegeneration could arise from increased levels of cytoplasmic TDP-43 and FUS, loss of nuclear TDP-43 and FUS, or increased formation of RNA granules, such as SGs. Animal models generated by overexpressing TDP-43 (mouse, Drosophila, and C. elegans) show age-dependent motor dysfunction and some evidence of neurodegeneration (Ash et al., 2010; Li et al., 2010; Liachko et al., 2010; Wils et al., 2010; Xu et al., 2010). However, these models do not develop large amounts of cytoplasmic TDP-43 inclusions. This could indicate that inclusion formation is not central to the disease process, or it could indicate that overexpressing TDP-43 causes toxicity by upregulating its normal biological function, independent of the pathological pro- 
cesses associated with ALS. For instance, recent studies identify large numbers of neuronal transcripts linked to synaptic functions whose splicing is affected by TDP-43 levels (Polymenidou et al., 2011). TDP-43 also binds numerous proteins linked to translational control (Freibaum et al., 2010). Overexpressing TDP-43 in animal models could affect splicing of synaptic proteins either through effects caused by TDP-43 dosage or effects caused by TDP-43 mutations.

Identification of key roles for TDP-43 and FUS in ALS suggests new concepts for the mechanisms of motorneuron diseases, as well as autism spectrum disorders. Both TDP-43 and FUS are aggregation-prone proteins that harbor prion-like domains and can be mutated in ALS, raising the intriguing possibility that they might sit at the tip of an iceberg for RBPs in ALS. Could additional RBPs, with properties similar to those of TDP-43 and FUS (e.g., aggregation prone) also contribute to the disease? Mutations that modify the tendency of other proteins to aggregate appear sufficient to induce ALS. Large polyglutamine expansions of ataxin-2 (>35) cause spinocerebellar ataxia-2 (Imbert et al., 1996; Sanpei et al., 1996). However, patients with moderate polyglutamine expansions in ataxin-2 (27-33 repeats) are at increased risk of ALS (Elden et al., 2010; Chen et al., 2011; Corrado et al., 2011; Lee et al., 2011; Ross et al., 2011; Van Damme et al., 2011). The role of ataxin-2 as a RBP that participates in RNA granule biology raises the possibility that factors that increase formation of RNA granules might increase the risk of disease. Individuals subjected to the stress of repetitive head trauma, such as professional athletes who played American football or soccer/European football, exhibit increased risk of ALS (Abel, 2007; Chen et al., 2007; Chio et al., 2009; McKee et al., 2010). A repeated cycle of aggregation and disaggregation, over the course of a lifetime might be prone to misregulation, leading to a failure to restore TDP-43 to the nucleus, resulting in its cytoplasmic accumulation and subsequent disease pathology. Perhaps polyglutamine expansions in ataxin-2 contribute to ALS risk by hampering the ability of stress granules to dissolve properly and/or by reducing the efficiency by which TDP-43 returns to the nucleus, with the cumulative effect being a greater propensity for TDP-43 to abnormally accumulate in the cytoplasm (Elden et al., 2010). This concept suggests that pathogenesis of ALS and other motorneuron disorders might be deeply rooted in core cell-biological pathways that are inherently prone to protein aggregation.

\section{Conclusion}

The family of RBPs includes $>500$ proteins. Many of these proteins have multiple functions and multiple sites of activity, ranging from the nucleus to the synapse. The predilection for mutations in RBPs to cause brain disorders suggests that the functional abnormalities are impacting on a feature selective to neurons. Mutations in RBPs associated with neurodegenerative diseases exhibit several characteristics in common: a strong tendency to aggregate and form RNA granules, and a role in mRNA transport. In the nucleus, both TDP-43 and SMN function in splicing. In contrast, FMRP exhibits a primary role in regulating synaptic efficacy, and loss of FMRP leads to mental retardation rather than neurodegeneration. The biology of RBPs also presents novel strategies for therapeutic intervention. Studies of FMRP delineate a critical role in translational repression that is tightly regulated by mTOR and able to be modulated by the mTORC1 inhibitor rapamycin. Increased aggregation of RBPs contributes to the pathology of ALS and FTLD-U. Aggregation of RBPs is reversible, which raises the possibility that pharmacological interventions moderating RBP aggregation might decrease the progression of motorneuron pathology and also delay symptomatic progression.

\section{References}

Abel EL (2007) Football increases the risk for Lou Gehrig's disease, amyotrophic lateral sclerosis. Percept Mot Skills 104:1251-1254.

Al-Ramahi I, Pérez AM, Lim J, Zhang M, Sorensen R, de Haro M, Branco J, Pulst SM, Zoghbi HY, Botas J (2007) dAtaxin-2 mediates expanded Ataxin-1-induced neurodegeneration in a Drosophila model of SCA1. PLoS Genet 3:e234.

Anderson P, Kedersha N (2008) Stress granules: the Tao of RNA triage. Trends Biochem Sci 33:141-150.

Ash PE, Zhang YJ, Roberts CM, Saldi T, Hutter H, Buratti E, Petrucelli L, Link CD (2010) Neurotoxic effects of TDP-43 overexpression in C. elegans. Hum Mol Genet 19:3206-3218.

Ashley CT Jr, Wilkinson KD, Reines D, Warren ST (1993) FMR1 protein: conserved RNP family domains and selective RNA binding. Science 262:563-566.

Banko JL, Poulin F, Hou L, DeMaria CT, Sonenberg N, Klann E (2005) The translation repressor 4E-BP2 is critical for eIF4F complex formation, synaptic plasticity, and memory in the hippocampus. J Neurosci 25:9581-9590.

Banko JL, Hou L, Poulin F, Sonenberg N, Klann E (2006) Regulation of eukaryotic initiation factor $4 \mathrm{E}$ by converging signaling pathways during metabotropic glutamate receptor-dependent long-term depression. J Neurosci 26:2167-2173.

Banko JL, Merhav M, Stern E, Sonenberg N, Rosenblum K, Klann E (2007) Behavioral alterations in mice lacking the translation repressor $4 \mathrm{E}-\mathrm{BP} 2$. Neurobiol Learn Mem 87:248-256.

Bassell GJ, Warren ST (2008) Fragile X syndrome: loss of local mRNA regulation alters synaptic development and function. Neuron 60:201-214.

Bosco DA, Lemay N, Ko HK, Zhou H, Burke C, Kwiatkowski TJ Jr, Sapp P, McKenna-Yasek D, Brown RH Jr, Hayward LJ (2010) Mutant FUS proteins that cause amyotrophic lateral sclerosis incorporate into stress granules. Hum Mol Genet 19:4160-4175.

Butler MG, Dasouki MJ, Zhou XP, Talebizadeh Z, Brown M, Takahashi TN, Miles JH, Wang CH, Stratton R, Pilarski R, Eng C (2005) Subset of individuals with autism spectrum disorders and extreme macrocephaly associated with germline PTEN tumour suppressor gene mutations. J Med Genet 42:318-321.

Cammalleri M, Lütjens R, Berton F, King AR, Simpson C, Francesconi W, Sanna PP (2003) Time-restricted role for dendritic activation of the mTOR-p70S6K pathway in the induction of late-phase long-term potentiation in the CA1. Proc Natl Acad Sci U S A 100:14368-14373.

Ceman S, O’Donnell WT, Reed M, Patton S, Pohl J, Warren ST (2003) Phosphorylation influences the translation state of FMRP-associated polyribosomes. Hum Mol Genet 12:3295-3305.

Chen H, Richard M, Sandler DP, Umbach DM, Kamel F (2007) Head injury and amyotrophic lateral sclerosis. Am J Epidemiol 166:810-816.

Chen Y, Huang R, Yang Y, Chen K, Song W, Pan P, Li J, Shang HF (2011) Ataxin-2 intermediate-length polyglutamine: a possible risk factor for Chinese patients with amyotrophic lateral sclerosis. Neurobiol Aging 32:1925.e1-5.

Chen YZ, Bennett CL, Huynh HM, Blair IP, Puls I, Irobi J, Dierick I, Abel A, Kennerson ML, Rabin BA, Nicholson GA, Auer-Grumbach M, Wagner K, De Jonghe P, Griffin JW, Fischbeck KH, Timmerman V, Cornblath DR, Chance PF (2004) DNA/RNA helicase gene mutations in a form of juvenile amyotrophic lateral sclerosis (ALS4). Am J Hum Genet 74:1128-1135.

Chen-Plotkin AS, Lee VM, Trojanowski JQ (2010) TAR DNA-binding protein 43 in neurodegenerative disease. Nat Rev Neurol 6:211-220.

Chio A, Calvo A, Dossena M, Ghiglione P, Mutani R, Mora G (2009) ALS in Italian professional soccer players: the risk is still present and could be soccer-specific. Amyotroph Lateral Scler 10:205-209.

Cleveland DW, Rothstein JD (2001) From Charcot to Lou Gehrig: deciphering selective motor neuron death in ALS. Nat Rev Neurosci 2:806-819.

Colombrita C, Zennaro E, Fallini C, Weber M, Sommacal A, Buratti E, Silani $\mathrm{V}$, Ratti A (2009) TDP-43 is recruited to stress granules in conditions of oxidative insult. J Neurochem 111:1051-1061.

Corrado L, Mazzini L, Oggioni GD, Luciano B, Godi M, Brusco A, D’Alfonso $S$ (2011) ATXN-2 CAG repeat expansions are interrupted in ALS pa- 
tients. Hum Genet. Advance online publication. Retrieved September 6, 2011. doi:10.1007/s00439-011-1000-2.

Darnell JC, Van Driesche SJ, Zhang C, Hung KY, Mele A, Fraser CE, Stone EF, Chen C, Fak JJ, Chi SW, Licatalosi DD, Richter JD, Darnell RB (2011) FMRP stalls ribosomal translocation on mRNAs linked to synaptic function and autism. Cell 146:247-261.

Dewey CM, Cenik B, Sephton CF, Dries DR, Mayer P 3rd, Good SK, Johnson BA, Herz J, Yu G (2011) TDP-43 is directed to stress granules by sorbitol, a novel physiological osmotic and oxidative stressor. Mol Cell Biol 31:1098-1108.

Dimitriadi M, Sleigh JN, Walker A, Chang HC, Sen A, Kalloo G, Harris J, Barsby T, Walsh MB, Satterlee JS, Li C, Van Vactor D, Artavanis-Tsakonas S, Hart AC (2010) Conserved genes act as modifiers of invertebrate SMN loss of function defects. PLoS Genet 6:e1001172.

Dormann D, Rodde R, Edbauer D, Bentmann E, Fischer I, Hruscha A, Than ME, Mackenzie IR, Capell A, Schmid B, Neumann M, Haass C (2010) ALS-associated fused in sarcoma (FUS) mutations disrupt Transportinmediated nuclear import. EMBO J 29:2841-2857.

Ehninger D, Han S, Shilyansky C, Zhou Y, Li W, Kwiatkowski DJ, Ramesh V, Silva AJ (2008) Reversal of learning deficits in a Tsc2 ${ }^{+/}$mouse model of tuberous sclerosis. Nat Med 14:843-848.

Elden AC, Kim HJ, Hart MP, Chen-Plotkin AS, Johnson BS, Fang X, Armakola M, Geser F, Greene R, Lu MM, Padmanabhan A, Clay-Falcone D, McCluskey L, Elman L, Juhr D, Gruber PJ, Rüb U, Auburger G, Trojanowski JQ, Lee VM, et al. (2010) Ataxin-2 intermediate-length polyglutamine expansions are associated with increased risk for ALS. Nature 466:1069-1075.

Emara MM, Ivanov P, Hickman T, Dawra N, Tisdale S, Kedersha N, Hu GF, Anderson P (2010) Angiogenin-induced tRNA-derived stress-induced RNAs promote stress-induced stress granule assembly. J Biol Chem 285:10959-10968.

Eulalio A, Helms S, Fritzsch C, Fauser M, Izaurralde E (2009a) A C-terminal silencing domain in GW182 is essential for miRNA function. RNA 15:1067-1077.

Eulalio A, Tritschler F, Izaurralde E (2009b) The GW182 protein family in animal cells: new insights into domains required for miRNA-mediated gene silencing. RNA 15:1433-1442.

Freibaum BD, Chitta RK, High AA, Taylor JP (2010) Global analysis of TDP-43 interacting proteins reveals strong association with RNA splicing and translation machinery. J Proteome Res 9:1104-1120.

Garber KB, Visootsak J, Warren ST (2008) Fragile X syndrome. Eur J Hum Genet 16:666-672.

Gelinas JN, Banko JL, Hou L, Sonenberg N, Weeber EJ, Klann E, Nguyen PV (2007) ERK and mTOR signaling couple beta-adrenergic receptors to translation initiation machinery to gate induction of protein synthesisdependent long-term potentiation. J Biol Chem 282:27527-27535.

Gennarelli M, Lucarelli M, Capon F, Pizzuti A, Merlini L, Angelini C, Novelli G, Dallapiccola B (1995) Survival motor neuron gene transcript analysis in muscles from spinal muscular atrophy patients. Biochem Biophys Res Commun 213:342-348.

Gibbings DJ, Ciaudo C, Erhardt M, Voinnet O (2009) Multivesicular bodies associate with components of miRNA effector complexes and modulate miRNA activity. Nat Cell Biol 11:1143-1149.

Goggin K, Beaudoin S, Grenier C, Brown AA, Roucou X (2008) Prion protein aggresomes are poly $(\mathrm{A})+$ ribonucleoprotein complexes that induce a PKR-mediated deficient cell stress response. Biochim Biophys Acta 1783:479-491.

Greenway MJ, Andersen PM, Russ C, Ennis S, Cashman S, Donaghy C, Patterson V, Swingler R, Kieran D, Prehn J, Morrison KE, Green A, Acharya KR, Brown RH Jr, Hardiman O (2006) ANG mutations segregate with familial and "sporadic" amyotrophic lateral sclerosis. Nat Genet 38:411-413.

Grohmann K, Schuelke M, Diers A, Hoffmann K, Lucke B, Adams C, Bertini E, Leonhardt-Horti H, Muntoni F, Ouvrier R, Pfeufer A, Rossi R, Van Maldergem L, Wilmshurst JM, Wienker TF, Sendtner M, RudnikSchöneborn S, Zerres K, Hübner C (2001) Mutations in the gene encoding immunoglobulin mu-binding protein 2 cause spinal muscular atrophy with respiratory distress type 1. Nat Genet 29:75-77.

Haramati S, Chapnik E, Sztainberg Y, Eilam R, Zwang R, Gershoni N, McGlinn E, Heiser PW, Wills AM, Wirguin I, Rubin LL, Misawa H, Tabin CJ, Brown R Jr, Chen A, Hornstein E (2010) miRNA malfunction causes spinal motor neuron disease. Proc Natl Acad Sci U S A 107:13111-13116.
Harris TW, Hartwieg E, Horvitz HR, Jorgensen EM (2000) Mutations in synaptojanin disrupt synaptic vesicle recycling. J Cell Biol 150:589-600.

Hoeffer CA, Klann E (2010) mTOR signaling: at the crossroads of plasticity, memory and disease. Trends Neurosci 33:67-75.

Hoeffer CA, Tang W, Wong H, Santillan A, Patterson RJ, Martinez LA, Tejada-Simon MV, Paylor R, Hamilton SL, Klann E (2008) Removal of FKBP12 enhances mTOR-Raptor interactions, LTP, memory, and perseverative/repetitive behavior. Neuron 60:832-845.

Hoeffer CA, Cowansage KK, Arnold EC, Banko JL, Moerke NJ, Rodriguez R, Schmidt EK, Klosi E, Chorev M, Lloyd RE, Pierre P, Wagner G, LeDoux JE, Klann E (2011) Inhibition of the interactions between eukaryotic initiation factors $4 \mathrm{E}$ and $4 \mathrm{G}$ impairs long-term associative memory consolidation but not reconsolidation. Proc Natl Acad Sci U S A 108:3383-3388.

Hou L, Klann E (2004) Activation of the phosphoinositide 3-kinase-Aktmammalian target of rapamycin signaling pathway is required for metabotropic glutamate receptor-dependent long-term depression. J Neurosci 24:6352-6361.

Hua Y, Zhou J (2004) Survival motor neuron protein facilitates assembly of stress granules. FEBS Lett 572:69-74.

Huber KM, Kayser MS, Bear MF (2000) Role for rapid dendritic protein synthesis in hippocampal mGluR-dependent long-term depression. Science 288:1254-1257.

Imbert G, Saudou F, Yvert G, Devys D, Trottier Y, Garnier JM, Weber C, Mandel JL, Cancel G, Abbas N, Dürr A, Didierjean O, Stevanin G, Agid Y, Brice A (1996) Cloning of the gene for spinocerebellar ataxia 2 reveals a locus with high sensitivity to expanded CAG/glutamine repeats. Nat Genet 14:285-291.

Jiang C, Schuman EM (2002) Regulation and function of local protein synthesis in neuronal dendrites. Trends Biochem Sci 27:506-513.

Jin P, Zarnescu DC, Ceman S, Nakamoto M, Mowrey J, Jongens TA, Nelson DL, Moses K, Warren ST (2004) Biochemical and genetic interaction between the fragile X mental retardation protein and the microRNA pathway. Nat Neurosci 7:113-117.

Kabashi E, Valdmanis PN, Dion P, Spiegelman D, McConkey BJ, Vande Velde C, Bouchard JP, Lacomblez L, Pochigaeva K, Salachas F, Pradat PF, Camu W, Meininger V, Dupre N, Rouleau GA (2008) TARDBP mutations in individuals with sporadic and familial amyotrophic lateral sclerosis. Nat Genet 40:572-574.

Kang H, Schuman EM (1996) A requirement for local protein synthesis in neurotrophin-induced hippocampal synaptic plasticity. Science 273:1402-1406.

Kelleher RJ 3rd, Bear MF (2008) The autistic neuron: troubled translation? Cell 135:401-406.

Kiebler MA, Bassell GJ (2006) Neuronal RNA granules: movers and makers. Neuron 51:685-690.

Klann E, Dever TE (2004) Biochemical mechanisms for translational regulation in synaptic plasticity. Nat Rev Neurosci 5:931-942.

Knowles RB, Sabry JH, Martone ME, Deerinck TJ, Ellisman MH, Bassell GJ, Kosik KS (1996) Translocation of RNA granules in living neurons. J Neurosci 16:7812-7820.

Kwiatkowski TJ Jr, Bosco DA, Leclerc AL, Tamrazian E, Vanderburg CR, Russ C, Davis A, Gilchrist J, Kasarskis EJ, Munsat T, Valdmanis P, Rouleau GA, Hosler BA, Cortelli P, de Jong PJ, Yoshinaga Y, Haines JL, Pericak-Vance MA, Yan J, Ticozzi N, et al. (2009) Mutations in the FUS/TLS gene on chromosome 16 cause familial amyotrophic lateral sclerosis. Science 323:1205-1208.

Kwon CH, Luikart BW, Powell CM, Zhou J, Matheny SA, Zhang W, Li Y, Baker SJ, Parada LF (2006) Pten regulates neuronal arborization and social interaction in mice. Neuron 50:377-388.

Lagier-Tourenne C, Polymenidou M, Cleveland DW (2010) TDP-43 and FUS/TLS: emerging roles in RNA processing and neurodegeneration. Hum Mol Genet 19:R46-R64.

Lee T, Li YR, Ingre C, Weber M, Grehl T, Gredal O, de Carvalho M, Meyer T, Tysnes OB, Auburger G, Gispert S, Bonini NM, Andersen PM, Gitler AD (2011) Ataxin-2 intermediate-length polyglutamine expansions in European ALS patients. Hum Mol Genet 20:1697-1700.

Lee YS, Pressman S, Andress AP, Kim K, White JL, Cassidy JJ, Li X, Lubell K, Lim do H, Cho IS, Nakahara K, Preall JB, Bellare P, Sontheimer EJ, Carthew RW (2009) Silencing by small RNAs is linked to endosomal trafficking. Nat Cell Biol 11:1150-1156.

Lefebvre S, Bürglen L, Reboullet S, Clermont O, Burlet P, Viollet L, Benichou B, Cruaud C, Millasseau P, Zeviani M, Le Paslier D, Frézal J, Cohen D, 
Weissenbach J, Munnich A, Melki J (1995) Identification and characterization of a spinal muscular atrophy-determining gene. Cell 80:155-165.

Lefebvre S, Burlet P, Liu Q, Bertrandy S, Clermont O, Munnich A, Dreyfuss G, Melki J (1997) Correlation between severity and SMN protein level in spinal muscular atrophy. Nat Genet 16:265-269.

Leung KM, van Horck FP, Lin AC, Allison R, Standart N, Holt CE (2006) Asymmetrical beta-actin mRNA translation in growth cones mediates attractive turning to netrin-1. Nat Neurosci 9:1247-1256.

Li Y, Ray P, Rao EJ, Shi C, Guo W, Chen X, Woodruff EA 3rd, Fushimi K, Wu JY (2010) A Drosophila model for TDP-43 proteinopathy. Proc Natl Acad Sci U S A 107:3169-3174.

Liachko NF, Guthrie CR, Kraemer BC (2010) Phosphorylation promotes neurotoxicity in a Caenorhabditis elegans model of TDP-43 proteinopathy. J Neurosci 30:16208-16219.

Ling SC, Albuquerque CP, Han JS, Lagier-Tourenne C, Tokunaga S, Zhou H, Cleveland DW (2010) ALS-associated mutations in TDP-43 increase its stability and promote TDP-43 complexes with FUS/TLS. Proc Natl Acad Sci U S A 107:13318-13323.

Liu Q, Fischer U, Wang F, Dreyfuss G (1997) The spinal muscular atrophy disease gene product, SMN, and its associated protein SIP1 are in a complex with spliceosomal snRNP proteins. Cell 90:1013-1021.

Liu-Yesucevitz L, Bilgutay A, Zhang YJ, Vanderwyde T, Citro A, Mehta T, Zaarur N, McKee A, Bowser R, Sherman M, Petrucelli L, Wolozin B (2010) Tar DNA binding protein-43 (TDP-43) associates with stress granules: analysis of cultured cells and pathological brain tissue. PLoS One 5:e13250.

Mackenzie IR, Bigio EH, Ince PG, Geser F, Neumann M, Cairns NJ, Kwong LK, Forman MS, Ravits J, Stewart H, Eisen A, McClusky L, Kretzschmar HA, Monoranu CM, Highley JR, Kirby J, Siddique T, Shaw PJ, Lee VM, Trojanowski JQ (2007) Pathological TDP-43 distinguishes sporadic amyotrophic lateral sclerosis from amyotrophic lateral sclerosis with SOD1 mutations. Ann Neurol 61:427-434.

Martin KC, Ephrussi A (2009) mRNA localization: gene expression in the spatial dimension. Cell 136:719-730.

Martin KC, Casadio A, Zhu H, Yaping E, Rose JC, Chen M, Bailey CH, Kandel ER (1997) Synapse-specific, long-term facilitation of Aplysia sensory to motor synapses: a function for local protein synthesis in memory storage. Cell 91:927-938.

McDonald KK, Aulas A, Destroismaisons L, Pickles S, Beleac E, Camu W, Rouleau GA, Vande Velde C (2011) TAR DNA-binding protein 43 (TDP-43) regulates stress granule dynamics via differential regulation of G3BP and TIA-1. Hum Mol Genet 20:1400-1410.

McKee AC, Gavett BE, Stern RA, Nowinski CJ, Cantu RC, Kowall NW, Perl DP, Hedley-Whyte ET, Price B, Sullivan C, Morin P, Lee HS, Kubilus CA, Daneshvar DH, Wulff M, Budson AE (2010) TDP-43 proteinopathy and motor neuron disease in chronic traumatic encephalopathy. J Neuropathol Exp Neurol 69:918-929.

Melko M, Bardoni B (2010) The role of G-quadruplex in RNA metabolism: involvement of FMRP and FMR2P. Biochimie 92:919-926.

Muddashetty RS, Nalavadi VC, Gross C, Yao X, Xing L, Laur O, Warren ST, Bassell GJ (2011) Reversible inhibition of PSD-95 mRNA translation by miR-125a, FMRP phosphorylation, and mGluR signaling. Mol Cell 42:673-688.

Narayanan U, Nalavadi V, Nakamoto M, Thomas G, Ceman S, Bassell GJ, Warren ST (2008) S6K1 phosphorylates and regulates fragile X mental retardation protein (FMRP) with the neuronal protein synthesisdependent mammalian target of rapamycin (mTOR) signaling cascade. J Biol Chem 283:18478-18482.

Neumann M, Sampathu DM, Kwong LK, Truax AC, Micsenyi MC, Chou TT, Bruce J, Schuck T, Grossman M, Clark CM, McCluskey LF, Miller BL, Masliah E, Mackenzie IR, Feldman H, Feiden W, Kretzschmar HA, Trojanowski JQ, Lee VM (2006) Ubiquitinated TDP-43 in frontotemporal lobar degeneration and amyotrophic lateral sclerosis. Science 314:130-133.

Nonis D, Schmidt MH, van de Loo S, Eich F, Dikic I, Nowock J, Auburger G (2008) Ataxin-2 associates with the endocytosis complex and affects EGF receptor trafficking. Cell Signal 20:1725-1739.

Oprea GE, Kröber S, McWhorter ML, Rossoll W, Müller S, Krawczak M, Bassell GJ, Beattie CE, Wirth B (2008) Plastin 3 is a protective modifier of autosomal recessive spinal muscular atrophy. Science 320:524-527.

Orr HT, Zoghbi HY (2007) Trinucleotide repeat disorders. Annu Rev Neurosci 30:575-621.
Parker R, Sheth U (2007) P bodies and the control of mRNA translation and degradation. Mol Cell 25:635-646.

Pearce LR, Alton GR, Richter DT, Kath JC, Lingardo L, Chapman J, Hwang C, Alessi DR (2010) Characterization of PF-4708671, a novel and highly specific inhibitor of p70 ribosomal S6 kinase (S6K1). Biochem J 431:245-255.

Pellizzoni L, Kataoka N, Charroux B, Dreyfuss G (1998) A novel function for SMN, the spinal muscular atrophy disease gene product, in premRNA splicing. Cell 95:615-624.

Penagarikano O, Mulle JG, Warren ST (2007) The pathophysiology of fragile X syndrome. Annu Rev Genomics Hum Genet 8:109-129.

Pesiridis GS, Lee VM, Trojanowski JQ (2009) Mutations in TDP-43 link glycine-rich domain functions to amyotrophic lateral sclerosis. Hum Mol Genet 18:R156-R162.

Piazzon N, Rage F, Schlotter F, Moine H, Branlant C, Massenet S (2008) In vitro and in cellulo evidences for association of the survival of motor neuron complex with the fragile $\mathrm{X}$ mental retardation protein. J Biol Chem 283:5598-5610.

Polymenidou M, Lagier-Tourenne C, Hutt KR, Huelga SC, Moran J, Liang TY, Ling SC, Sun E, Wancewicz E, Mazur C, Kordasiewicz H, Sedaghat Y, Donohue JP, Shiue L, Bennett CF, Yeo GW, Cleveland DW (2011) Long pre-mRNA depletion and RNA missplicing contribute to neuronal vulnerability from loss of TDP-43. Nat Neurosci 14:459-468.

Ralser M, Nonhoff U, Albrecht M, Lengauer T, Wanker EE, Lehrach H, Krobitsch S (2005) Ataxin-2 and huntingtin interact with endophilin-A complexes to function in plastin-associated pathways. Hum Mol Genet 14:2893-2909.

Ran I, Laplante I, Bourgeois C, Pépin J, Lacaille P, Costa-Mattioli M, Pelletier J, Sonenberg N, Lacaille JC (2009) Persistent transcription- and translation-dependent long-term potentiation induced by mGluR1 in hippocampal interneurons. J Neurosci 29:5605-5615.

Richter JD, Klann E (2009) Making synaptic plasticity and memory last: mechanisms of translational regulation. Genes Dev 23:1-11.

Ross OA, Rutherford NJ, Baker M, Soto-Ortolaza AI, Carrasquillo MM, Dejesus-Hernandez M, Adamson J, Li M, Volkening K, Finger E, Seeley WW, Hatanpaa KJ, Lomen-Hoerth C, Kertesz A, Bigio EH, Lippa C, Woodruff BK, Knopman DS, White CL 3rd, Van Gerpen JA, et al. (2011) Ataxin-2 repeat-length variation and neurodegeneration. Hum Mol Genet 20:3207-3212.

Sanpei K, Takano H, Igarashi S, Sato T, Oyake M, Sasaki H, Wakisaka A, Tashiro K, Ishida Y, Ikeuchi T, Koide R, Saito M, Sato A, Tanaka T, Hanyu S, Takiyama Y, Nishizawa M, Shimizu N, Nomura Y, Segawa M, et al. (1996) Identification of the spinocerebellar ataxia type 2 gene using a direct identification of repeat expansion and cloning technique, DIRECT. Nat Genet 14:277-284.

Satterfield TF, Jackson SM, Pallanck LJ (2002) A Drosophila homolog of the polyglutamine disease gene SCA2 is a dosage-sensitive regulator of actin filament formation. Genetics 162:1687-1702.

Sau D, Rusmini P, Crippa V, Onesto E, Bolzoni E, Ratti A, Poletti A (2011) Dysregulation of axonal transport and motorneuron diseases. Biol Cell 103:87-107.

Schratt G (2009) microRNAs at the synapse. Nat Rev Neurosci 10:842-849.

Schuske KR, Richmond JE, Matthies DS, Davis WS, Runz S, Rube DA, van der Bliek AM, Jorgensen EM (2003) Endophilin is required for synaptic vesicle endocytosis by localizing synaptojanin. Neuron 40:749-762.

Sharma A, Lambrechts A, Hao le T, Le TT, Sewry CA, Ampe C, Burghes AH, Morris GE (2005) A role for complexes of survival of motor neurons $(\mathrm{SMN})$ protein with gemins and profilin in neurite-like cytoplasmic extensions of cultured nerve cells. Exp Cell Res 309:185-197.

Sharma A, Hoeffer CA, Takayasu Y, Miyawaki T, McBride SM, Klann E, Zukin RS (2010) Dysregulation of mTOR signaling in fragile X syndrome. J Neurosci 30:694-702.

Si K, Choi YB, White-Grindley E, Majumdar A, Kandel ER (2010) Aplysia $\mathrm{CPEB}$ can form prion-like multimers in sensory neurons that contribute to long-term facilitation. Cell 140:421-435.

Sreedharan J, Blair IP, Tripathi VB, Hu X, Vance C, Rogelj B, Ackerley S, Durnall JC, Williams KL, Buratti E, Baralle F, de Belleroche J, Mitchell JD, Leigh PN, Al-Chalabi A, Miller CC, Nicholson G, Shaw CE (2008) TDP-43 mutations in familial and sporadic amyotrophic lateral sclerosis. Science 319:1668-1672.

Steward O, Levy WB (1982) Preferential localization of polyribosomes un- 
der the base of dendritic spines in granule cells of the dentate gyrus. J Neurosci 2:284-291.

Steward O, Schuman EM (2001) Protein synthesis at synaptic sites on dendrites. Annu Rev Neurosci 24:299-325.

Sun Z, Diaz Z, Fang X, Hart MP, Chesi A, Shorter J, Gitler AD (2011) Molecular determinants and genetic modifiers of aggregation and toxicity for the ALS disease protein FUS/TLS. PLoS Biol 9:e1000614.

Tang SJ, Reis G, Kang H, Gingras AC, Sonenberg N, Schuman EM (2002) A rapamycin-sensitive signaling pathway contributes to long-term synaptic plasticity in the hippocampus. Proc Natl Acad Sci U S A 99:467-472.

Thomas MG, Loschi M, Desbats MA, Boccaccio GL (2011) RNA granules: the good, the bad and the ugly. Cell Signal 23:324-334.

Tiedge H, Brosius J (1996) Translational machinery in dendrites of hippocampal neurons in culture. J Neurosci 16:7171-7181.

Tsokas P, Ma T, Iyengar R, Landau EM, Blitzer RD (2007) Mitogenactivated protein kinase upregulates the dendritic translation machinery in long-term potentiation by controlling the mammalian target of rapamycin pathway. J Neurosci 27:5885-5894.

Vance C, Rogelj B, Hortobágyi T, De Vos KJ, Nishimura AL, Sreedharan J, Hu X, Smith B, Ruddy D, Wright P, Ganesalingam J, Williams KL, Tripathi V, Al-Saraj S, Al-Chalabi A, Leigh PN, Blair IP, Nicholson G, de Belleroche J, Gallo JM, et al. (2009) Mutations in FUS, an RNA processing protein, cause familial amyotrophic lateral sclerosis type 6. Science 323:1208-1211.

Van Damme P, Veldink JH, van Blitterswijk M, Corveleyn A, van Vught PW, Thijs V, Dubois B, Matthijs G, van den Berg LH, Robberecht W (2011) Expanded ATXN2 CAG repeat size in ALS identifies genetic overlap between ALS and SCA2. Neurology 76:2066-2072.

Waelter S, Boeddrich A, Lurz R, Scherzinger E, Lueder G, Lehrach H,
Wanker EE (2001) Accumulation of mutant huntingtin fragments in aggresome-like inclusion bodies as a result of insufficient protein degradation. Mol Biol Cell 12:1393-1407.

Wang DO, Martin KC, Zukin RS (2010) Spatially restricting gene expression by local translation at synapses. Trends Neurosci 33:173-182.

Wang IF, Wu LS, Chang HY, Shen CK (2008) TDP-43, the signature protein of FTLD-U, is a neuronal activity-responsive factor. J Neurochem 105:797-806.

Wils H, Kleinberger G, Janssens J, Pereson S, Joris G, Cuijt I, Smits V, Ceuterick-de Groote C, Van Broeckhoven C, Kumar-Singh S (2010) TDP-43 transgenic mice develop spastic paralysis and neuronal inclusions characteristic of ALS and frontotemporal lobar degeneration. Proc Natl Acad Sci U S A 107:3858-3863.

Wu L, Wells D, Tay J, Mendis D, Abbott MA, Barnitt A, Quinlan E, Heynen A, Fallon JR, Richter JD (1998) CPEB-mediated cytoplasmic polyadenylation and the regulation of experience-dependent translation of alphaCaMKII mRNA at synapses. Neuron 21:1129-1139.

Xu YF, Gendron TF, Zhang YJ, Lin WL, D’Alton S, Sheng H, Casey MC, Tong J, Knight J, Yu X, Rademakers R, Boylan K, Hutton M, McGowan E, Dickson DW, Lewis J, Petrucelli L (2010) Wild-type human TDP-43 expression causes TDP-43 phosphorylation, mitochondrial aggregation, motor deficits, and early mortality in transgenic mice. J Neurosci 30:10851-10859.

Zhou J, Blundell J, Ogawa S, Kwon CH, Zhang W, Sinton C, Powell CM, Parada LF (2009) Pharmacological inhibition of mTORC1 suppresses anatomical, cellular, and behavioral abnormalities in neural-specific Pten knock-out mice. J Neurosci 29:1773-1783. 